\title{
The Socio-Economic Effects of Medical Unions Strikes on the Health Sector of Akwa Ibom State of Nigeria
}

\author{
Madara Joseph Essien \\ Department of Economics, University of Uyo, Akwa Ibom State, NIGERIA \\ *E-mail for correspondence: madarajobe4th@gmail.com
}

https://doi.org/10.18034/abr.v8i2.157

\begin{abstract}
This study was a cross-sectional descriptive survey conducted with the general objective to describe the socioeconomic effects of medical union strikes on Nigeria's health sector, with particular focus on Akwa Ibom State. Four research questions were formulated that guided the study. Data were collected from respondents who constituted staff, medical students and patients of Akwa Ibom State public hospitals. These formed the population of the study while 150 individuals were randomly selected as sample size. Double sampling technique was adopted while simple random sampling method was used to achieve the purpose of adopting it. The instruments used for data collection was survey questionnaire and oral interview with a tape recorder. The criterion-related validity and test-re-test reliability were methods adopted to test for the validity and reliability of research instruments. The data collected were analyzed using descriptive analytics techniques such as frequency distribution, measures of central tendency, percentages and measures of dispersion. From the analysis, it was revealed that the incessant health workers strikes are fundamentally caused by poor remuneration, denial to salary review and nonpayment of accrued salaries. It was also seen that negative socioeconomic effects of which the major ones included avoidable deaths, poor health complications and disease spread outweighed the positive socioeconomic effects which were salary review, payment of accrued wages, provision of medical equipment and improved welfare of health workers. This was viewed in terms of their impacts on the economic indices of the nation. The study recommends among other things that government should pay health workers salaries regularly and improved infrastructure of health centres to enhance service delivery. On the other hand, workers should make demands that are moderate and not beyond the capacity of their employers and should provide certain essential services while on strike.
\end{abstract}

Key words: Health workers, Strike, Socioeconomic, Nigeria, Akwa Ibom, Medical unions

\section{INTRODUCTION}

The health sector in Nigeria is charged with the responsibility of providing qualitative and accessible health care delivery in order to ensure a healthy population in the country. On the funding and operation, the health sector is segmented into two (2) major categories - the public and the private health institutions. Public health institutions are those owned and operated by government, while those classified into the private sector are owned and operated by private individuals either for commercial purpose of making profit or charity, as in the case of those operated by non-governmental organizations. The operational structure of public health sector includes the tertiary health institutions such as the teaching hospitals and Federal Medical Centres (FMCs), both supervised by the Federal Ministry of Health.

The operation of the health sector in Nigeria in the past two decades has become nightmarish rather that providing adequate, qualitative, accessible and effective health care services to the people. Many elites rather seek health care services in foreign countries. Public health institutions in Nigeria are afflicted with numerous problems such as poor leadership structure, lack of government goodwill on implementation of international best practices, under-funding/mismanagement, poor infrastructures, under propensity on foreign health tourism among the elite, quackery, corruption, poor attitude of health personnel, brain drain and the associated challenge of shortage of manpower, 
indiscriminate and incessant industrial actions and supremacy tussle among health care professional unions. These and many more have impaired the efficiency of the health delivery system in the country, thereby resulting in the country's poor health indices which place it close to the bottom in almost all developmental indices when compared with other countries of the world. The World Economic Forum (WEF) in their 2016/17 Global competition index report placed Nigeria health system as the $127^{\text {th }}$ out of 138 countries evaluated.

The Nigerian economy has been disturbed and its economic activities disrupted from time to time due to labour union strike actions. Its first recorded labour strike was on June 21, 1945 where about 150,000 clerical and nonclerical workers in the Nigerian Civil Service were demanding for better wages due to the rising cost of living brought about by the Second World War. This was possible because workers formed themselves into a labour union. The essence of the union amongst others was negotiation of wages, work rules, complaint procedures, rules governing hiring, firing and promotion of workers, workplace safety and policies to enforce strikes.

Despite the fact that the Trade Dispute Act of 1976 declared strike illegal; and the institutionalization of "no work, no pay" rule strike actions in Nigeria has no abated. The Nigerian health system has experienced exponential increase in industrial conflict. It appears that no part of public service in Nigeria has experienced more strikes than the health sector. In recent times there are many incidences of health workers strike; but the most interesting is the case of the Federal Medical Centre in Owerri. The health workers came to work every day but spend their time singing and praying on the hospital grounds, while ignoring their patients in the wards, protesting against the privatization of some of the hospital services. In many other parts of the country public sector hospitals were closed for about half of the year due strikes by doctors. But as soon as they returned, other health sector workers under the aegis of the Joint Health Sector Unions (JOHESU) proceeded to strike from November 2014 to February, 2015. Several patients including those in critical conditions were forced to discharge themselves following paralysis of medical and clinical services. It also made children to be abandoned in the children ward. All accident and emergency (A \& E) department were under lock and key. Wards were deserted. This has impacted on the health care system, leading to several avoidable deaths, complication and outgoing medical tourism, as the wealthy seek health services abroad.

It can be seen so far that strikes in the health sector have assumed an astronomical proportion. This is occasioned by the inability of the government to settle her health workers duly and at the right time. Also, for harmony to exist in any productive sector of a country, there need to be an efficient interplay of both individuals (workers) and the country (employer). Perhaps, strikes are sustained because this interplay is not efficient enough and so disharmony becomes the order of the day in the sector. The impact of these different strikes on the health sector tends to place more negative values on local and national economy. Thus, this work aimed at analyzing the socio-economic dynamics of these strikes and how it impacts on the health sector of Nigeria - focusing on the health sector of Akwa Ibom State.

\section{Statement of the Problem}

Nigeria as a country has suffered from several health workers' strikes involving different categories of health workers. Frequent health workers' strikes result in the closure of public health care institutions preventing Nigerians access to quality health services. Health care workers are specialized in different areas; an optician does a different work from a surgeon and so on. It is the integration of all their works as well as the interrelationship that exists in these different medical services that makes the health system, as a whole function effectively. Thus, if any of these categories withholds services due to strikes, the health sector will definitely not function efficiently. This posed serious hardship to the relations of patients as they complained they had no money to go to private hospitals. Strikes paralyze healthcare delivery services at the detriment of people's lives. It has so far sent many people to their untimely graves. Incessant strikes do not only create animosity, acrimony and supremacy tussle among various units and departments in the public health institutions but it also cripple the health system economic-wise. On the account of this observation, the study aim to highlights the economic consequences of the strike actions. It set out to analyze the positive and negative socio-economic effect of medical union strike on health sector of Akwa Ibom State. In other words, the work aims to show how medical union strike impact on the State's economic indices.

\section{ObJectives OF the Study}

- To determine the fundamental causes of medical unions' strike in Nigeria.

- To show the positive socio-economic effects of medical unions' strikes on the health sector in Nigeria.

- To show the negative socio-economic effects of medical unions' strikes on the health sector in Nigeria.

- To suggest measures to curbing the negative socioeconomic effects of medical unions' strikes on the health sector in Nigeria.

\section{RESEARCH QUESTIONS}

- What are the fundamental causes of medical unions' strike?

- What are the positive socio-economic effects of medical unions' strikes on the health sector?

- What are the negative socio-economic effects of medical unions' strikes on the health sector? 
- What suggestive measures can help curb the negative socio-economic effects of medical unions' strikes on the health sector?

\section{LITERATURE REVIEW}

\section{Definitions of Strike}

Strike can be defined as an expression of dissatisfaction within an employment relationship especially those pertaining to employment contract and the collective bargaining. This refers to the incomparable interest of workers and employers in the workplace, disagreement arising from the terms and conditions of employment, clashes resulting from opposing views held by the management participants in the workplace fashioned according to their steps and positions on the organization location. This does not mean that best management practice in administration and communication can bring about absence of industrial conflict. A total absence of conflict would be unbelievable, boring and a strong indication that such conflicts are being suppressed. Conflict is a necessary aspect of human relations (Eyo and Francis, 2017). In other words, conflict necessarily defines any relationship whether professional or personal.

\section{Causes of Strikes}

Industrial conflict is said to arise when there is deviation from the expectation relating to the terms and conditions of work especially when it affects the employees (Alkerman and Torenvlied, 2017). Industrial conflict also arise as a result of incompatible interest of workers and employees in the working and employment, clashes resulting from opposing view held by workers about their relationship (Owoye, 1994). Abuza (2016) opines that industrial conflict can be caused when there are absenteeism, output restriction, job changing negligence, accident at work, break of contract of policy, unconscious forms of protests and individualization etc. Most health workers' strikes are caused basically by poor remunerations, poor medical facilities, non-payment of accrued salaries, irregularities in the payment of salaries, inadequate infrastructures/funding poor working environment, government's incentive to the health workers' requests and lots more (Oleribe et al, 2016).

\section{Impact of Strikes}

Generally, strike actions lead to economic instability. It worsens the general socioeconomic status of every individual within the geographical region where it has existed and even beyond. Equally, increase in foreign direct investment would continue to elude the country as most wealthy people will seek or even establish health care centers abroad. As the government procrastinate in meeting the demands of health workers, strikes prolong causing avoidable deaths, health complications, diseases spread etc (Adegun, 1977). Kelly and Nicloson (1980) maintains that strikes occur globally but the impact appears to be more severely felt in less developed countries because of the poorer socio-economic circumstances and embedded infrastructural deficiencies. Striking workers frequently face a less of income, job insecurity, and emotional distress, plus long hours of work for those who chose not to participate in the strike action (Owoye, 1994). Further, whether or not their demands are finally met, doctors have been involved in strikes usually end up disillusioned and de-motivated and may end up emigrating oversees or relocating within the country thereby leading to internal or external brain drain.

\section{MetHOdOLOGY}

The study took place in three general hospitals in Akwa Ibom State each of which were selected from the headquarters of the three senatorial districts in the State. The hospitals were General Hospital Ikot Ekpene, General Hospital Oron and General Hospital Itu Mbang. The study population comprised clinical staff, medical staff, non-medical staff, medical students, and patients of Akwa Ibom State public hospitals. The sample size adopted for the study was 150 respondents. The methodological approach adopted for the study was quantitative method which involved cross-sectional survey that included use of structured questionnaire to collect relevant data from sampled respondents. The research instrument was tested for its validity and reliability based on criterion-related and test-re-test methods. Double sampling technique was used to collect the relevant data for both the quantitative and qualitative studies. Data collected from the sampling were analyzed using univariate analytic techniques such as frequency distribution, measures of central tendency, percentages and measures of dispersion. The relevant data and statistical outcome obtained from the study were used to answer the research questions.

\section{Data Sources/Variable Definitions}

The study was based data obtained from both primary and secondary sources. The primary data used in this approach were obtained from a sample drawn from the study population. All these were done through the distribution of questionnaire, and by oral interviews with the respondents. The secondary data were drawn from journals, lecture guide, textbooks, periodicals, gazette of the Federal Government of Nigeria (FGN) and Akwalbom State Government (AKSG), relevant official records from the State Ministry of Health, and other research work relating to this topic published and unpublished.

Dependent Variable: The dependent variable is the health sector of Akwa Ibom State. This comprises clinical staff, medical staff, non-medical staff, medical students, and patients of Akwa Ibom State public hospitals. The data has been sourced primarily from General Hospital Ikot Ekpene, Emmanuel Hospital Eket and General Hospital Itu Mbang.

Independent Variable: The independent variable is socioeconomic effects of medical union strikes. Socio-economic 
is defined in terms of social and economic effects. Socioeconomic effect is defined as social phenomena that bear economic influence on human productivity in terms of resource (goods and services) production, distribution and utilization. This can be defined in negative and positive terms. The social effects of labour unions' strikes have been studied and discussed in some literature (Kelly and Nidiolson, 1980; Adalsteinsson, 2007; Chikanda, 2004). However, there is dearth of literature on social effects of medical union strikes considered from economic perspective. Social effects of strike also bear economic consequences for the affected society, in terms of optimal production, distribution and utilization of resources bringing about economic synthetic effects on microeconomics. Consistent yet reflecting with a majority of empirical studies, this work determined social effects of medical union strike using economic indicators.

\section{Result Presentation ANd InTERPRetation}

Table 1: Gender Distribution of Respondents

\begin{tabular}{|c|c|c|}
\hline Gender & $\mathrm{F}$ & $\%$ \\
\hline Male & 65 & 48.3 \\
\hline Female & 85 & 56.7 \\
\hline Total & 150 & 100 \\
\hline
\end{tabular}

Table 1 shows the distribution of respondents among male and female genders. From the table, it is observed that $43.3 \%$ of the respondents were females while $56.7 \%$ represents female population and it is the majority of the total population sampled.

Table 2: Age Distribution of Respondents

\begin{tabular}{|c|c|c|}
\hline Age & F & $\%$ \\
\hline $18-28$ & 25 & 16.7 \\
\hline $29-39$ & 15 & 10.0 \\
\hline $40-50$ & 33 & 22.0 \\
\hline $51-61$ & 53 & 35.3 \\
\hline $62 \&$ above & 24 & 16.0 \\
\hline Total & 150 & 100 \\
\hline
\end{tabular}

Table 2 represents age distribution of respondents in the survey. From the table, it is observed that respondents between age 51 - 61 represents highest number of respondents at $35.3 \%$ while respondents in the age bracket 29 - 39 carry the least percent $(10.0 \%)$. Respondents of ages $40-$ 50 carry the second highest percent of $22 \%$ followed by $16.7 \%$ which represent respondents in 18-28 age bracket. Finally, $16.0 \%$ represent respondents' ages of 62 and above.

Table 3: Distribution of professional status of respondents

\begin{tabular}{|c|c|c|}
\hline Professional Status & $\mathrm{F}$ & $\%$ \\
\hline Medical staff & 80 & 53.3 \\
\hline Non-medical staff & 24 & 16.0 \\
\hline Patients & 27 & 18.0 \\
\hline Others & 19 & 12.7 \\
\hline Total & 150 & 100 \\
\hline
\end{tabular}

Table 3 shows the professional distribution of respondents. It is observed that health workers carry the highest percentage of $53.3 \%$, non-health workers have $16.0 \%$ while $18.0 \%$ and $12.7 \%$ represent the population of patients and others with respect to this distribution respectively.

Table 4: Distribution of workers' years in service in hospital

\begin{tabular}{|c|c|c|}
\hline No. of years & $\mathrm{F}$ & $\%$ \\
\hline $1-10$ & 18 & $17 \%$ \\
\hline $11-20$ & 23 & $22 \%$ \\
\hline $21-30$ & 30 & $29 \%$ \\
\hline Above 30 & 33 & $32 \%$ \\
\hline Total & 104 & $100 \%$ \\
\hline
\end{tabular}

Table 4 shows the distribution of workers' years in service in the hospital. It is observed that the highest percentage of $32.0 \%$ represent staff who have worked $32 \%$ between 21-30years while the least percent, $19.3 \%$ represent staff that have worked between 1-10 years.

\section{Research Question One}

What are the fundamental causes of medical union strikes?

Table 5: Causes of Workers Strikes

\begin{tabular}{|l|c|c|}
\hline \multicolumn{1}{|c|}{ X } & $\mathrm{F}$ & $\%$ \\
\hline Poor remuneration and denied salary review & 34 & 22.7 \\
\hline Unpaid salary & 60 & 40.0 \\
\hline Unpaid leave grant and other entitlements & 14 & 9.3 \\
\hline $\begin{array}{l}\text { Poor working environment and dearth } \\
\text { equipment }\end{array}$ & 11 & 7.3 \\
\hline Default of MoU by government & 26 & 17.3 \\
\hline No idea & 05 & 3.3 \\
\hline Total & 150 & 100 \\
\hline
\end{tabular}

From the table, it was observed that, poor remuneration and denial to salaries review $(22.7 \%)$, unpaid solar/ other entitlement $(40 \%)$, unpaid leave grants $(9.3 \%)$, poor working environment and dearth equipment (7.3\%), and default of MoU by government (17.3\%). Unpaid salaries anda21'V other entitlement was identified as the main cause of medical union strike in the state with $40 \%$ while poor working environment/ dearth equipment was identified as the least cause of medical union strike with $7.3 \%$.

\section{Research Question Two}

What are the positive socio-economic effects of medical union strikes on the health sector?

Table 6: Positive socio-economic effects of medical unions' strikes

\begin{tabular}{|l|c|c|}
\hline X & F & $\%$ \\
\hline $\begin{array}{l}\text { Increment of health workers' salary \& } \\
\text { payment of other entitlements }\end{array}$ & 66 & 44 \\
\hline Provision of medical equipments & 30 & 20 \\
\hline Improved welfare of health workers & 22 & 14.7 \\
\hline Improved performance of health workers' services & 32 & 21.3 \\
\hline Total & $\mathbf{1 5 0}$ & $\mathbf{1 0 0}$ \\
\hline
\end{tabular}

To answer the Research Question 2, the researcher drew conclusion from Table 6. From the table, it was observed 
that positive socioeconomic effects of medical union strike include: salaries increment $(44 \%)$, provision of medical equipment $(20 \%)$, improvement of health workers welfare $(14.7 \%)$, and improved performance of health workers $(21.3 \%)$. Salary increment and payment of all entitlement was considered as the most positive outcome of medieval Union strike in Akwa Ibom State at $44 \%$.

\section{Research Question Three}

What are the negative socio-economic effects of medical union strikes on the health sector?

Figure 1: Bar chart showing negative socio-economic effects of medical workers strike

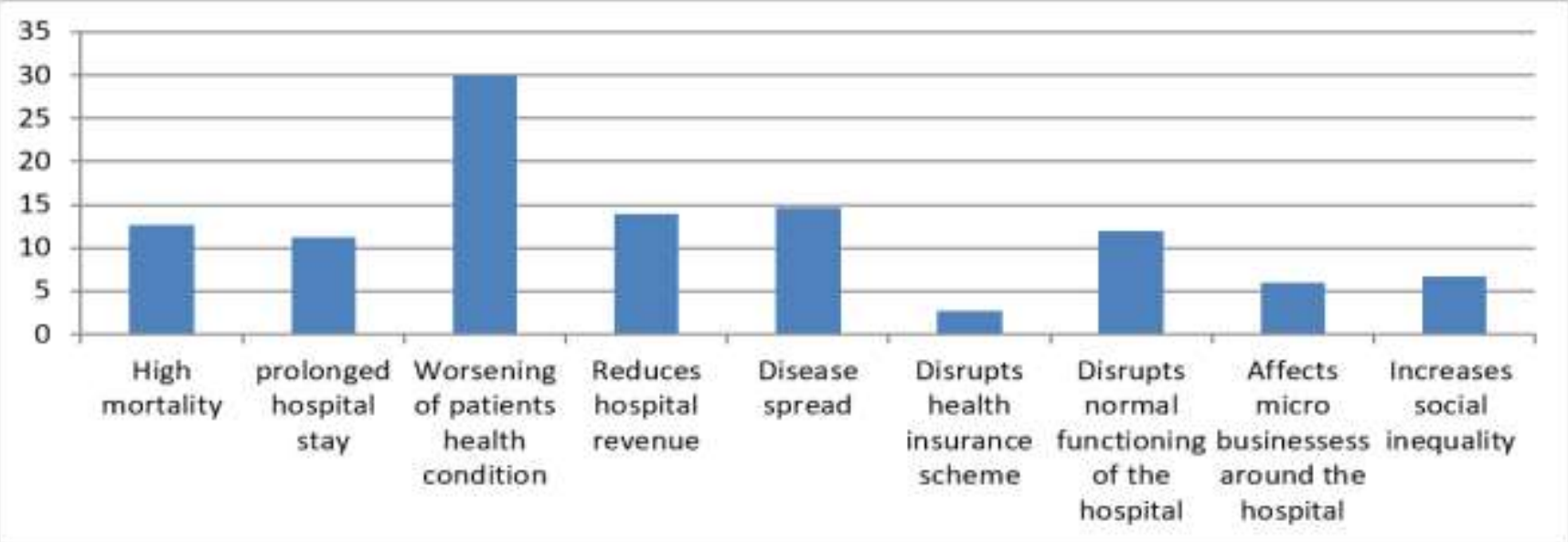

To answer the research question, the researcher drew conclusion from Figure 1. From the figure, it was observed that negative socioeconomic effects of medical union strike include: high mortality $(12.7 \%)$, prolonging hospital stay $(11.3 \%)$, worsening of patients health conditions $(20 \%)$, reduction in hospital revenue $(14 \%)$, spreading of disease $(14.7 \%)$, disrupts of health insurance scheme $(2.7 \%)$, disruption of normal functioning of the health sector $(12 \%)$, increased social inequality $(6.7 \%)$, and disruption of micro enterprises $(6 \%)$. It was observed that worsening of patients' health conditions ranked as the most negative effect of medical union strike in the State.

\section{Research Question Four}

What are the measures to curb the negative socioeconomic effects of medical workers strikes?

Figure 2 A pie chart showing measures of curbing the negative socio-economic effects of medical workers' strike

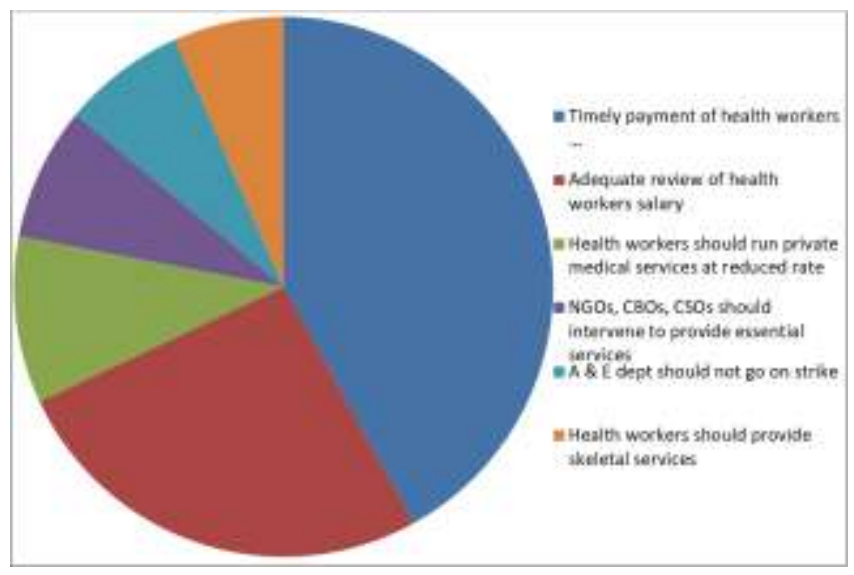

To answer the research question, the researcher drew conclusion from Figure 2. From the figure, it was observed that the measures to curb the negative socio-economic effects of medical union strike include: timely payment of health worker's salaries $(42 \%)$, adequate salary review $(26 \%)$, workers in accident \&emergency wards should never go on strike $(7.4 \%)$, private hospitals should be run at a reduced cost during strike $(10 \%)$, provision of essential medical services by CSOs, NGOs, CBOs and other recognized organizations $(8 \%)$, and provision of skeletal services by health worker $(6.6 \%)$. It was observed that timely payments of health workers salaries and other entitlements ranked as the most adequate measure to curb the negative effects of medical union strikes.

\section{Discussion}

The aim of the study was to describe the socioeconomic effects of medical union strike on the health sector in Nigeria. The study was also designed to determine any significant relationship between medieval union strike and the health sector. The results indicate that there were positive and negative socioeconomic effects of medical union strike on Akwa Ibom health sector. Figure 1 indicates that the negative socioeconomic effects of medical union strike on the health sector included: prolong hospitalization of patients, hospital revenue reduction, spreading of disease, disruption of health insurance scheme, high mortality, increased social inequality and disruption of micro enterprises. This finding corroborates the results of earlier studies that medical union strikes have negative effects on health sector (Chikanda 2004; Oleribe et al, 2016; Akkerman \& Torenvlied 2017). 
The study indicates that the positive socioeconomic effective of medical unions' strikes include: increment of salaries, provision of medical equipment, improved welfare package for health workers and improved performance of health workers. This study seems to set the pace in this direction, in the sense that the researcher could not find literature that studied positive socioeconomic effects of medical unions' strikes. It seems that previous studies were focused on negative socioeconomic effects of medical unions' strikes.

On the causes of medical union strike, the study also struck accord with previous studies. It indicates that the fundamental causes of medical union strike in Akwa Ibom included unpaid salaries, denial to salary review, unpaid leave grant and other entitlements, poor workings environment and dearth equipment, and default of $\mathrm{MoU}$ by government. Earlier studies by researchers have also identified these factors as the fundamental causes of medical workers strike (Kelly and Nicholson 1980; Adalsteinsson 2007; Chima 2013). In particular, this study corroborates recent cross-sectional descriptive study carried out by Obinna Oleribe and co-researchers about the causes of medical union strike in Nigeria between 2013-2015. In their findings, it was shown that the main cause of medical union's strike in Nigeria was demand for salaries review at $82 \%$. In this study, demand for higher salary was the second most important cause of medical union strike in Akwa Ibom State at 22.7\% following unpaid salaries which was identified as the most important cause if medical Union strikes in Akwa Ibom State at $40 \%$. These findings are in line with what Maslow thesis that strike will always disrupt the flow of services if the basic physiological needs of the services providers are not adequately met while the reverse would be the case if such basic needs are met.

Finally, on the measures that could be adopted to curb the negative effects of medical union strikes, the study shows the various measures that could help curb the negative effects of strikes if adopted. These included: timely payment of health workers salaries and other entitlement, adequate review of health workers salaries, A\&E department should not retrieve medical serves, health care providers in private hospitals should operate at reduced cost, NGOs, CBOs, and CSOs should provide skeletal services (Figure 2). In this study, Figure 2 indicate that the two most important/useful measures to curb negative effects of strike are timely payment of health worker's Salaries / other entitlements and adequate sales review which ranked $42 \%$ and $26 \%$ respectively.

\section{IMPLICATIONS}

The result of this study has serious social and economic implications for the society in terms of its effects on microeconomic and macro-economic indices of the country. The impact is usually higher in developing economies. In other words, in less developed economies, medical unions' strikes further worsens already worse socioeconomic circumstances to the extent that citizens lack or have little options to turn to. From the study, 20\% of the respondents reported that medical union strike worsen patients' health conditions, $14.7 \%$ reported that it leads to spreading of disease, and $6.7 \%$ indicated that medical union strike increases social inequality (Figure 1).

In Nigeria about $70 \%$ of the population is reported to live below poverty line, this means that the little money individuals and household have is used to purchase essential services such as food, shelter, clothing and healthcare. Yet, healthcare is cheaper in governmentmanaged facilities. However, when the health workers within such facilities down tools, this decreases the ability of many individuals and households to obtain healthcare because they usually lack the wherewithal to finance such alternatives. This leads to worsening of the conditions of both inpatients and outpatients and also leads to spreading of diseases in the case of contagious diseases. This also means that the affected population would be less productive in terms of their involvement in pursuit of economic productive ends achieve through exerting labour. At the macro-economic level, the aggregate productivity of the national economy will be negatively affected.

From the study, it was reported that medical Union strike leads to increased social inequality. This means that during strike the gap between the poor and the rich as well as between the male and female gender becomes increasingly obvious. Many rich people could obtain medical services at private clinics during which fewer poor could do same. In the same vein, fewer female than their male counterparts could obtain medical services at private healthcare facility. The impact of worsening social inequality implies that, most of the disadvantaged group could not contribute to economic growth at per capita level. This would also have negative effects on national aggregates. $12.7 \%$ of respondents indicated that medical union strike increases mortality rate (Figure 1); particularly that of children who are known to be more vulnerable to disease (Todaro and Smith 2012).

Studies have indicated that healthier people earn higher wages. In Cote d' Ivoire it was reported that unhealthy people, that is people who were likely to lose a day of work per month due to illness earned 19\% lower than healthy people (Todaro and Smith 2012).This further means that, a healthy population is a prerequisite for successful economic development. This study indicates that medical unions' strike worsens outpatients' health and reduces the opportunity of the population to obtain healthcare services (Figure 1). Good health standard in a population is unimportant to achieve goals of poverty reduction. As Todaro and Smith (2012) note, "if parents are two weak, unhealthy, and unskilled to be productive enough to support their family, the children have to work. But if the children work, they cannot get the education 
they need, so when they grow up, they will have to send their own children to work "(p.403). Thus, the cycle of poverty and low productivity extend across generations. Health and education are pivotal to economic development (Todaro and Smith 2012).

Strike itself is based on microeconomic self-interest. Umo (1993) noted that "the economic world draws its dynamism from the self-interest motivation of individuals, firms and governments in response to some desirable incentives" (p.3). Umo (1993) also noted that every economic activity is a response to a reward or loss system. The existence of appropriate incentives elicits appropriate (correct) economic behavior. The level of efficiency in public institutions depends on the structure of positive and or negative incentives facing the operators (Umo 1993). People work to earn a living. Health workers also work to earn a living. Their motivation to work is the reward that they get. However, when the incentive is distorted, they are bound to react. A restoration of these incentives means restoration of efficiency to the system. We can say that strike is an economic corrective mechanism necessary for the effective functioning of the work environment in terms of protecting the reward system of the economy thereby, ensuring efficiency and productivity.

\section{Conclusion AND ReCOMmEndations}

From the findings of the study, it can be concluded that strikes interrupt the smooth flow of medical services to citizens and it is slowly and irredeemably destroying the public health system. This is a result of incompatible demand of the employers and her employees. Also, the study also reveal that denial of salary review and accumulated salary arrears were identified as major causes of medical union strikes. It is noteworthy that the impact of industrial conflict is felt in the productive sector of the economy, both at microeconomic and macroeconomic levels. When people's health conditions get worsened or there is high mortality rate due to strikes, they become unable to shoulder their responsibilities effectively and hence cannot make progress that will contribute to the growth of the society. This will also reduce labour force drastically both currently and in the future and will in turn affect aggregate production and income negatively. Poor health and negative economic growth are inextricably linked. Improving the health of a nation's citizens can directly result in economic growth. When human capital is deteriorated, economic productivity is at stake. Health workers have been seen as valuable assets to the society. Their intrinsic value, in terms of human capital, should be respected rather than focusing on economic productivity that may be derived from it. Whenever that is ignored, labour unions utilize the threat of strike (Owoye, 1994). Poorly paid health workers are consistently searching for greener pastures, and may in turn resign from their current services to take up greener opportunities in foreign countries. When this happens, the health sector faces the problem of brain drain which results in the reduction of both internally generated income and foreign reserves. Effective public health systems are essential for providing care for the sick and for instituting measures that promote wellness. It breeds healthy citizens that make up a healthy labour force that determines the growth of the state and the country at large.

\section{REFERENCES}

Abuza, E.A. (2016). A Reflection on Regulation of Strikes in Nigeria. Commonwealth Law Bulletin, 4(2), 3-7.

Adalsteinsson, G.D. (2007). Can Strike Theories Introduced in 1960s and 1970s Explain Different Levels of Strike Trends in the Nordic Countries in 1980s and 1990s? Working papers series, Institute of Business Research, University of Iceland.

Adegun, A.A. (1977). Strikes and Institutionalization of Labour Protest: The Case of Nigeria. Proceedings of Seminar on Third World Strikes, Institute for Social Studies, The Hague, pp. 1-30.

Alkerman, A. and Tolenvlied (2017). Effect of Industrial Conflict between and within Organizations: Contagion in Collective Bargaining and Deterioration of Work Relations. Paper presented at the Annual Meeting of the Dutch and Flourish Political Science Associations, Leuven, May 27-28.

Chikanda, A. (2004). Skilled Health Professionals Migration and its Impacts on Health Delivery in Zimbabwe. Working paper No.4, Centre on Migration, Policy and Society, University of Oxford.

Chima, S.C. (2013). Global Medicine: Is it Ethical or Morally Justifiable for Doctors and Health Workers to go on Strike? Medical Ethics, 14(1), 1-10.

Eyo, E.B. and Francis, D.A.I (2017). A Colloquy on Violence and Non-violence: Towards a Complementary Conflict Resolution. American Journal of Social Issues and Humanities, 7(2), 137-150.

Kelly, J.E. and Nicloson, N. (1980). The Causation of Strikes: A Review of Theoretical Approaches and Potential Contribution of Social Psychology. Human Relations, 339(12), 83-88.

Oleribe, O.O., Ezieme, I.P., Oladipo, O., Akinola, E.P., Udofia, D. and Taylor-Robinson, S.D. (2016). Industrial Action by Healthcare Workers in Nigeria in 2013-2015: An Inquiry into Causes, Consequences and Control - a Cross-sectional Descriptive Study. Human Resources for Health, 14(46), 1-10.

Owoye, O. (1994). Wage Determination and Strike Activity in Nigeria. Journal of African Economics, 3(3).

Todaro, M.P. and Smith, S.C. (2012). Economic Development, $11^{\text {th }}$ ed. Boston: Addison-Wesley.

Umo, J.U. (1993). Economics: An African Perspective. Lagos: Millennium Text Publishers Ltd.

$$
--0-
$$


Online Archive: https://abc.us.org/ojs/index.php/abr/issue/archive 